\title{
Myco-metabolites as biological control agents against the two-spotted spider mite, Tetranychus urticae Koch (Acari: Tetranychidae)
}

\author{
Mohamed E. Osman ${ }^{1}$, Amany A. Abo Elnasr ${ }^{1}$, Mohamed A. Nawar ${ }^{2}$ and Gohyza A. Hefnawy ${ }^{2 *}$
}

\begin{abstract}
Fungi are a promising source for bioactive secondary metabolites against various agricultural pests. Soil samples were collected from the rhizosphere of various plants at El-Khatatba, Egypt, in May 2016. Sixty-two fungal isolates were locally isolated and screened against Tetranychus urticae Koch (Acari: Tetranychidae). Four fungal strains, showed potent control activities, were morphologically identified. Laboratory evaluation of the crude extracts of the selected strains, Aspergillus melleus, A. terreus, Emericella nidulans, and Chaetomium globosum, exhibited LC 50 values of $10.27,33.05,14.68$, and $22.40 \mathrm{mg} / \mathrm{ml}$ against females of $T$. urticae, respectively. Correspondent $L C_{50}$ values that exhibited on eggs were $8.81,23.17,11.66$, and $11.05 \mathrm{mg} / \mathrm{ml}$. Consequently, secondary metabolites of $A$. melleus were separated by liquid chromatography/mass spectrometry. Compounds separated from the active fraction were identified as mellamide, ochratoxin C, nodulisporic acid, 7-Oxocurvularin, and 6-(4'-hydroxy-2'-methyl phenoxy)$(-)$-(3R)-mellein. Obtained secondary metabolites are promising sources for biopesticides to be used in bio-rationale control of T. urticae.
\end{abstract}

Keywords: Tetranychus urticae, Fungal metabolites, Biological control, Aspergillus melleus

\section{Background}

Crop production is decreased annually by $18-26 \%$ because of arthropod pests (Culliney 2014). The two-spotted spider mite, Tetranychus urticae Koch (Acari: Tetranychidae), can infest more than 200 plant species all over the world. Many reports showed that T. urticae can cause harsh damage to many agricultural crops such as vegetables, fruits, and ornamental plants (Fasulo and Denmark 2000). Management of T. urticae by using synthetic acaricides has been widely applied (Attia et al. 2013). Due to health and environmental hazards caused by chemical pesticides in addition to their effects on other non-target organisms such as predators, their use has been firmly regulated (Horikoshi et al. 2017). Moreover, the development of acaricidal resistance in T. urticae is highly increasing since they have an outstanding potential to develop such resistance. Therefore, the development of

\footnotetext{
* Correspondence: gohyzahefnawy@yahoo.com

${ }^{2}$ Department of Plant Protection, Desert Research Centre, Cairo, Egypt

Full list of author information is available at the end of the article
}

new acaricides with novel modes of action is increasingly needed (Marcic 2012).

Currently, many chemicals used in agriculture to control pests are originally derived from microbial metabolites (Horikoshi et al. 2017). Fungi and fungal metabolites exhibit a high toxicity to insects and mite pests; however, they show low toxicity to non-target organisms (Ragavendran and Natarajan 2015). Researchers thought that fungi use their products as well as mycotoxins as chemical defenses against different targets including insects and mites. For instance, mycotoxins such as aflatoxin B and trichothecenes exhibit toxicity to many insect pests (Srivastava et al. 2009). Consequently, microbial metabolites may be promising resources in a novel pesticide development (Horikoshi et al. 2017).

Beside predatory mites, plant extracts, and essential oils, microbial metabolites may be also promising tools in bio-rationale control of T. urticae (Attia et al. 2013). For example, thuringiensin produced by $B$. thuringiensis showed a potent acaricidal efficiency on T. urticae, $T$. 
cinnabarinus (Neal Jr et al. 1987), and Panonychus ulmi Koch (Vargas Mesina 1993). Pseudomonas fluorescens exhibited a strong efficacy on adults of Oligonychus coffeae Nietner under laboratory conditions (Roobakkumar et al. 2011). Also, an actinomycete-derived product, abamectin (avermectin) produced from Streptomyces avermitilis, demonstrated highly toxic effects on $T$. cinnabarinus (Wu and Liu 1997), T. urticae, Phyllocoptruta oleivora, Panonychus citri, and T. turkestani Ugarov and Nikolski (Putter et al. 1981).

The present study aimed to evaluate the control potential of ethyl acetate extract produced by different fungal strains against $T$. urticae under laboratory conditions. In addition, the active compound/s produced by the most effective strain will be separated, purified, and identified.

\section{Materials and methods}

All experiments were conducted at the laboratories of Plant Protection Department, Desert Research Centre, Egypt (2016-2018).

\section{Collection of soil samples}

Soil samples were collected from EL-Khatatba, Egypt, in May 2016. Plants at different fields were examined by the aid of a $\times 10$ magnification lens for spider mite infestation. Samples were collected from the rhizosphere of the spider mite-infested plants at a depth of $10-15 \mathrm{~cm}$ under the soil surface. Soil samples $(500 \mathrm{~g}$ each) were placed in sterilized polyethylene bags and stored at $4{ }^{\circ} \mathrm{C}$ until use.

\section{Isolation, purification, and identification of fungi by cultural and morphological methods}

Isolation of soil fungi was done by a serial dilution method. Two types of culture media were used for isolation of fungi: potato dextrose agar (PDA) and Czapek's Dox agar supplemented with yeast extract $(5 \mathrm{~g} / \mathrm{l})$. All media were supplemented with chloramphenicol antibiotic $(25 \mathrm{mg} / \mathrm{l})$. Isolation of fungi was carried out from dilutions of $10^{-2}$ and $10^{-3}$, where $0.5 \mathrm{ml}$ was taken from each dilution and placed into Petri dishes with a solid media, then spread, using a sterilized glass spreader and was left for $30 \mathrm{~min}$ before incubation at $28^{\circ} \mathrm{C}$ for $4-7$ days. Each morphological distinct, fungal colony was sub-cultured and purified, using standard techniques.

\section{Primary screening of fungal isolates against $T$. urticae}

Sixty-two fungal isolates were screened for their control activity by testing their culture filtrates against adult spider mite females. Four discs $(1 \mathrm{~cm})$ were cut from fresh culture of each fungal isolate and inoculated in $100 \mathrm{ml}$ of potato dextrose broth. The broth cultures were incubated in shaking incubator at $28^{\circ} \mathrm{C}, 150 \mathrm{rpm}$ for 7 days. Fungal cultures were filtered, using sterilized
Table 1 Effect of culture filtrate of potent isolates on the females of Tetranychus urticae

\begin{tabular}{ll}
\hline Isolate code & No. dead females (Mean \pm SE) \\
\hline Control & $0.67^{\mathrm{j}} \pm 0.33$ \\
KF8 & $3.00^{\mathrm{ghi}} \pm 0.58$ \\
Chaetomium globosum & $8.00^{\mathrm{a}} \pm 0.58$ \\
Rhizoctonia sp. & $5.33^{\mathrm{cde}} \pm 0.33$ \\
Myrothecium verrucaria & $3.67^{\mathrm{fi}} \pm 0.33$ \\
Stachybotrys chartarum & $3.33^{\mathrm{fi}} \pm 0.33$ \\
Trichoderma sp.1 & $4.33^{\mathrm{dg}} \pm 0.33$ \\
Alternaria sp. & $4.00^{\mathrm{eh}} \pm 0.58$ \\
Aspergillus melleus & $6.00^{\mathrm{bc}} \pm 0.58$ \\
KF24 & $3.33^{\mathrm{fi}} \pm 0.33$ \\
Purpureocillium lilacinum & $4.00^{\mathrm{eh}} \pm 0.58$ \\
KF29 & $2.33^{\mathrm{i}} \pm 0.33$ \\
Trichoderma sp. 2 & $5.33^{\mathrm{ce}} \pm 0.33$ \\
KF34 & $4.00^{\mathrm{eh}} \pm 0.58$ \\
KF35 & $3.33^{\mathrm{fi}} \pm 0.33$ \\
Chaetomium globosum 2 & $5.33^{\mathrm{ce}} \pm 0.33$ \\
Aspergillus terreus & $5.67^{\mathrm{cd}} \pm 0.33$ \\
KF42 & $2.33^{\mathrm{i}} \pm 0.33$ \\
Emericella nidulans & $7.33^{\mathrm{ab}} \pm 0.67$ \\
KF46 & $2.67^{\mathrm{hi}} \pm 0.33$ \\
Emericella sp. & $4.33^{\mathrm{dg}} \pm 0.33$ \\
KF52 & $3.00^{\mathrm{gi}} \pm 0.58$ \\
KF53 & $4.00^{\mathrm{eh}} \pm 0.58$ \\
Cladosporium sp. & $2.67^{\mathrm{hi}} \pm 0.33$ \\
KF55 & $3.67^{\mathrm{fi}} \pm 0.88$ \\
KF56 & $4.67^{\mathrm{cf}} \pm 0.67$ \\
Kenicellium sp. & $3.33^{\mathrm{fi}} \pm 0.33$ \\
\hline F val & $4.00^{\mathrm{eh}} \pm 0.58$ \\
$2.67^{\mathrm{hi}} \pm 0.33$ \\
\hline
\end{tabular}

$F$ value $=14.157$, degree of freedom $=126$, Values are mean no. of dead mites \pm standard error of three replicates. Different letters in the same column indicate a significant difference $(P=0.05)$ according to Duncan's multiple range test

filter papers and centrifuged. Finally, the filtrates were preserved in refrigerator at $4{ }^{\circ} \mathrm{C}$ until use within a week to avoid any contamination or alteration of metabolites. Bioassay of fungal filtrates on spider mites was carried out by leaf-dipping method. Three mulberry leaf discs $(25 \mathrm{~mm})$ were immersed for $5 \mathrm{~s}$ in each fungal filtrate and dried at room temperature. The treated leaf discs were placed on wetted cotton wool in Petri dishes. Each was lined with cotton lining to prevent mites from escaping. Ten females were transferred to each leaf disc, using a fine paintbrush and incubated at $25^{\circ} \mathrm{C}$. Control was immersed in potato dextrose broth and mortality rates were observed after 5 days. 


\section{Selection and identification of the most potent isolates Morphological identification}

Four isolates (KF23, KF45, KF40, and KF9) out of 62 were selected for further investigation, as they achieved $>50 \%$ mortality in T. urticae. Cultures were grown on Czapek's yeast extract agar and incubated at $28^{\circ} \mathrm{C}$ for $7-10$ days. The identification of the most potent isolates was carried out on morphological basis, using culture characteristics, e.g., growth rate, color, and pigmentation, as well as microscopic features, e.g., conidiophores, conidia, production of sclerotia, and dimensions of the different microscopic fungal structures. The results were confirmed by the scientists of Mycological Centre, Assiut University, Egypt.

\section{Effect of crude extract of the selected isolates on adult females of $T$. urticae}

Twelve plugs of freshly prepared culture of each fungal isolate were inoculated in $300 \mathrm{ml}$ potato dextrose broth media and incubated in shaking incubator at $28^{\circ} \mathrm{C}, 150$ rpm for 10 days. After incubation time, each fungal culture was filtered and subjected to extraction with ethyl acetate (1:1) triple. The crude extract was dried, using a rotary evaporator, and stored in a freezer until use. Four concentrations $(5,10,20,30 \mathrm{mg} / \mathrm{ml})$ were prepared from the crude extract of each fungal isolate. Bioassay of each extract was undertaken using the leaf dipping method. Leaf discs of $25 \mathrm{~mm}$ were immersed in each of the four concentrations, and another disc group was dipped in ethanol and used as a check and left to dry at room temperature. Treated leaf discs were placed on wetted cotton in Petri dishes $(9 \mathrm{~cm})$ and lined with a cotton lining to prevent spider mites from escaping, and then 20 females were transferred and incubated at $25^{\circ} \mathrm{C}$. The mortality rates were recorded after 3 days. Each concentration was replicated three times.

\section{Effect of crude extract of the selected isolates on eggs of T. urticae}

The ovicidal activity of the previously prepared concentrations of ethyl acetate extract of selected isolates was tested as follows: 10 females were placed on mulberry leaf discs $(25 \mathrm{~mm})$, prepared in $9 \mathrm{~cm}$ Petri dish to obtain same-aged eggs to be used in the tests. Twenty-four hours later, females were removed from the discs, eggs were counted, and three leaf discs, carrying eggs, were dipped into each concentration. The control discs were dipped in $70 \%$ ethanol and were left to dry. Observations continued daily until hatching of eggs in the control group.

\section{Confirmation of the most potent strain by DNA sequencing}

The strain was cultured on PDA overlaid with cellophane at $27^{\circ} \mathrm{C}$ for $3-5$ days. Total genomic DNA (deoxyribonucleic acid) was directly extracted from fungal mycelia of the KF23 strain, using the Quick-DNA ${ }^{\text {ma }}$ Fungal/Bacterial Microprep Kit (Zymo research \#D6007). The internal transcribed spacers (ITS1 and ITS4) were amplified using the universal primer pair ITS1 (5'CTTGGTCATTTAGAGGAAGTAA-3') and ITS4 (5'TCCTCCGCTTATTGATATGC-3') (White et al. 1990) in a $50-\mu \mathrm{l}$ reaction mixture comprising $5 \mu \mathrm{l}$ of genomic

Table 2 Effect of ethyl acetate extract on females of Tetranychus urticae (after $72 \mathrm{~h}$ exposure)

\begin{tabular}{|c|c|c|c|c|c|c|c|c|}
\hline & Control & $5(\mathrm{mg} / \mathrm{ml})$ & $10(\mathrm{mg} / \mathrm{ml})$ & $20(\mathrm{mg} / \mathrm{ml})$ & $30(\mathrm{mg} / \mathrm{ml})$ & Fvalue & $\mathrm{LC}_{50}(\mathrm{mg} / \mathrm{ml})$ & Slope \\
\hline \multicolumn{9}{|c|}{ Aspergillus melleus } \\
\hline Mean (no. of dead mites) \pm SE & $0.0^{e} \pm 0.0$ & $3.67^{d} \pm 0.33$ & $11.00^{c} \pm 1.15$ & $14.33^{b} \pm 0.33$ & $18.33^{a} \pm 1.67$ & $65.74^{* * *}$ & 10.27 & 2.738 \\
\hline$\%$ of dead mites & 0.0 & 18.33 & 55.00 & 71.67 & 91.67 & - & & \\
\hline \multicolumn{9}{|c|}{ Emericella nidulans } \\
\hline Mean (no. of dead mites) \pm SE & $0.0^{\mathrm{d}} \pm 0.0$ & $1.67^{d} \pm 0.67$ & $5.33^{c} \pm 0.88$ & $14.00^{b} \pm 1.00$ & $16.33^{\mathrm{a}} \pm 0.33$ & $115.31^{* * *}$ & 14.68 & 3.052 \\
\hline$\%$ of dead mites & 0.0 & 8.33 & 26.67 & 70.00 & 81.67 & - & & \\
\hline \multicolumn{9}{|c|}{ Chaetomium globosum } \\
\hline Mean (no. of dead mites) \pm SE & $0.0^{\complement} \pm 0.0$ & $0.67^{\complement} \pm 0.67$ & $1.33^{c} \pm 0.33$ & $7.00^{b} \pm 1.15$ & $15.33^{\mathrm{a}} \pm 1.20$ & $62.96^{* * *}$ & 22.40 & 3.240 \\
\hline$\%$ of dead mites & 0.0 & 3.33 & 6.67 & 35.00 & 76.67 & - & & \\
\hline \multicolumn{9}{|c|}{ Aspergillus terreus } \\
\hline Mean (no. of dead mites) $\pm S E$ & $0.0^{c} \pm 0.0$ & $0.33^{c} \pm 0.33$ & $0.67^{c} \pm 0.33$ & $4.00^{b} \pm 0.58$ & $11.33^{a} \pm 0.33$ & $171.83^{* * *}$ & 33.05 & 2.898 \\
\hline$\%$ of dead mites & 0.0 & 1.67 & 3.33 & 20.00 & 56.67 & - & & \\
\hline
\end{tabular}

Values are mean no. of dead mites \pm standard error of three replicates. $\mathrm{df}=10$. Different letters in the same row indicate a significant difference according to Duncan's multiple range test

***Values are significant at $P=0.05$ levels 
Table 3 Effect of ethyl acetate extract on egg hatchability of Tetranychus urticae

\begin{tabular}{|c|c|c|c|c|c|c|c|c|}
\hline & Control & $5(\mathrm{mg} / \mathrm{ml})$ & $10(\mathrm{mg} / \mathrm{ml})$ & $20(\mathrm{mg} / \mathrm{ml})$ & $30(\mathrm{mg} / \mathrm{ml})$ & $F$ value & $\mathrm{LC}_{50}(\mathrm{mg} / \mathrm{ml})$ & Slope \\
\hline \multicolumn{9}{|c|}{ Aspergillus melleus } \\
\hline Mean (no. of eggs) $\pm \mathrm{SE}$ & $1.00^{d} \pm 0.58$ & $4.67^{c} \pm 0.67$ & $12.67^{\mathrm{b}} \pm 0.67$ & $19.00^{\mathrm{a}} \pm 0.58$ & $20.00^{a} \pm 0.0$ & $230.464^{* * *}$ & 8.81 & 3.458 \\
\hline$\%$ of unhatched eggs & 0.00 & 18.52 & 58.92 & 90.91 & 95.96 & - & & \\
\hline \multicolumn{9}{|c|}{ Emericella nidulans } \\
\hline Mean (no. of eggs) $\pm S E$ & $1.00^{\mathrm{e}} \pm 0.58$ & $3.00^{d} \pm 0.58$ & $7.00^{c} \pm 1.00$ & $17.00^{b} \pm 0.58$ & $20.00^{a} \pm 0.0$ & $179.5^{* * *}$ & 11.66 & 3.923 \\
\hline$\%$ of unhatched eggs & 0.00 & 10.10 & 30.30 & 80.81 & 95.96 & - & & \\
\hline \multicolumn{9}{|c|}{ Chaetomium globosum } \\
\hline Mean (no. of eggs) \pm SE & $1.00^{\mathrm{e}} \pm 0.58$ & $4.33^{d} \pm 0.88$ & $10.00^{c} \pm 1.53$ & $13.00^{b} \pm 0.58$ & $20.00^{\mathrm{a}} \pm 0.0$ & $73.309^{* * *}$ & 11.05 & 3.010 \\
\hline$\%$ of unhatched eggs & 0.00 & 16.84 & 45.45 & 60.61 & 95.96 & - & & \\
\hline \multicolumn{9}{|c|}{ Aspergillus terreus } \\
\hline Mean(no. of eggs) $\pm S E$ & $1.00^{\mathrm{e}} \pm 0.58$ & $3.00^{d} \pm 0.58$ & $5.67^{c} \pm 0.67$ & $9.00^{b} \pm 0.58$ & $13.33^{\mathrm{a}} \pm 0.33$ & $77.214^{* * *}$ & 23.17 & 1.960 \\
\hline$\%$ of unhatched eggs & 0.00 & 10.10 & 23.57 & 40.40 & 62.29 & - & & \\
\hline
\end{tabular}

Values are mean no. of unhatched eggs \pm standard error of three replicates. $\mathrm{df}=10$. Different letters in the same row indicate a significant difference according to Duncan's multiple range test

***Values are significant at $P=0.05$ levels

DNA, $1 \mu \mathrm{l}$ of each primer, $25 \mu \mathrm{l}$ Maxima Hot Start PCR Master Mix (Thermo K1051), and $18 \mu \mathrm{l}$ of sterile distilled water. The polymerase chain reaction (PCR) was carried out with the following parameters: an initial denaturation at $95^{\circ} \mathrm{C}(10 \mathrm{~min}), 35$ cycles of primer denaturation at $95^{\circ} \mathrm{C}(30 \mathrm{~s})$, annealing at $57^{\circ} \mathrm{C}(1 \mathrm{~min})$, and extension at $72^{\circ} \mathrm{C}(1 \mathrm{~min} 30 \mathrm{~s})$. A final elongation step was allowed at $72{ }^{\circ} \mathrm{C}$ for $10 \mathrm{~min}$. The PCR products were purified using Gene JET ${ }^{\mathrm{Tm}}$ PCR Purification Kit (Thermo K0701), according to the manufacturer's

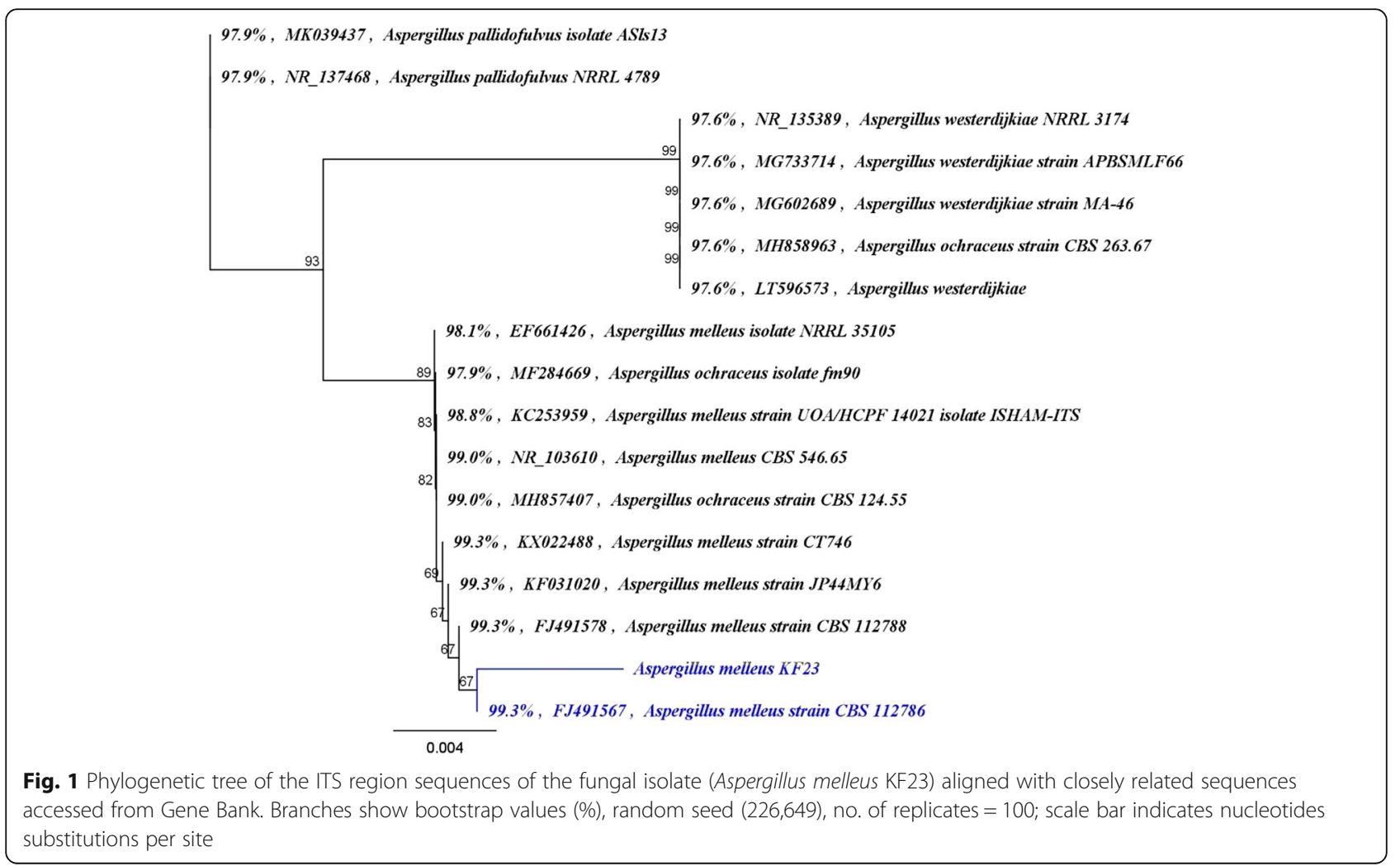




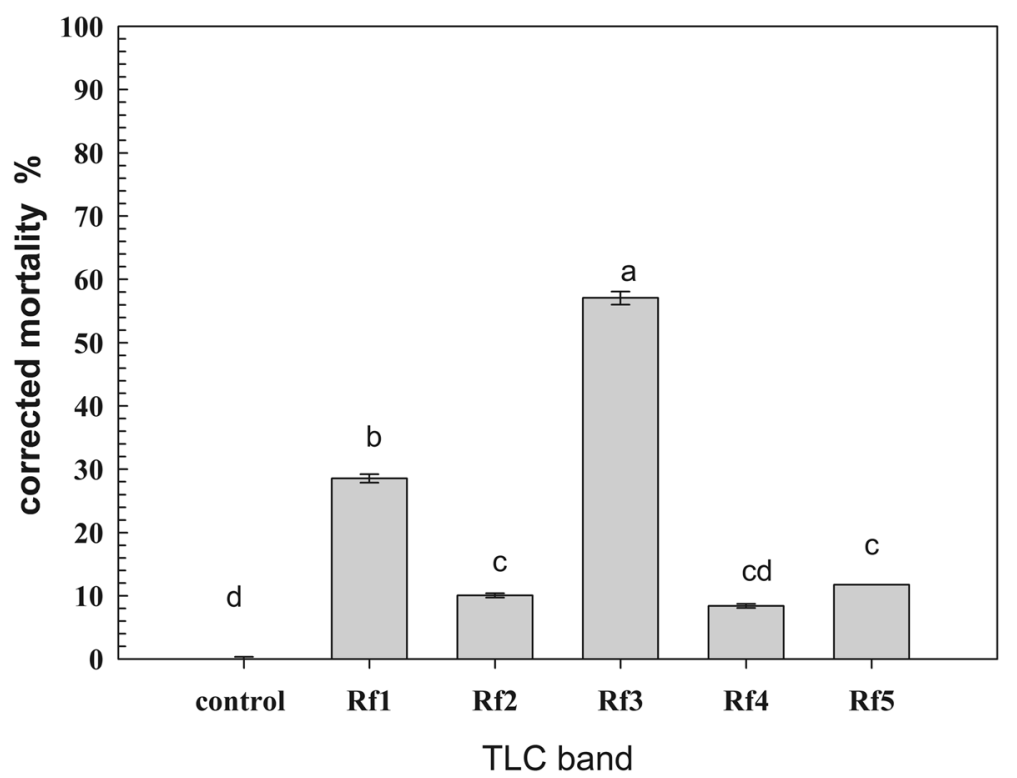

Fig. 2 Lethal activity of TLC fractions of ethyl acetate extract of A. melleus on T. urticae. Error bars are corresponding to standard error. Different letters (superscript $a$ and $b$ ) indicate a significant difference according to Duncan's multiple range test

instructions. Sequencing was done at GATC Company Germany by using ABI 3730xl DNA sequencer and using forward and reverse primers. The sequence obtained was subjected into Geneious pro 8.9 software and compared to ITS sequences available in Gene Bank by blast analysis. Finally, the phylogenetic tree was constructed to establish the taxonomic rank of the fungus.

\section{Separation, purification, and identification of acaricidal secondary metabolites produced by $A$. melleus Preparation of extracellular crude extract from A. melleus} Twenty-five Erlenmeyer flasks $(250 \mathrm{ml})$, each containing $100 \mathrm{ml}$ of PDB media supplemented with sucrose 3\% (w/ v), ammonium sulfate $0.75 \%(\mathrm{w} / \mathrm{v})$, at initial $\mathrm{pH}$ value 4 and the flasks, were incubated at $30^{\circ} \mathrm{C}$ for 6 days under static conditions. After the incubation period, the culture was collected and filtered by muslin cloth, then the clear filtrate was collected and subjected to extraction by Ethyl acetate triple (1:1), then the extraction solvent was dried, using vacuum under reduced pressure at $40^{\circ} \mathrm{C}$, and the crude extract was collected.

\section{Separation of active compounds by thin-layer chromatography}

Aluminum sheets $(20 \times 20 \mathrm{~cm})$ with pre-coated silica gel 60 F254 (Merck, Germany) was used to separate active metabolites. The crude extract was applied in the form of bands at $1 \mathrm{~cm}$ from the bottom of the plate, using a capillary tube. Subsequently, the thin-layer chromatography

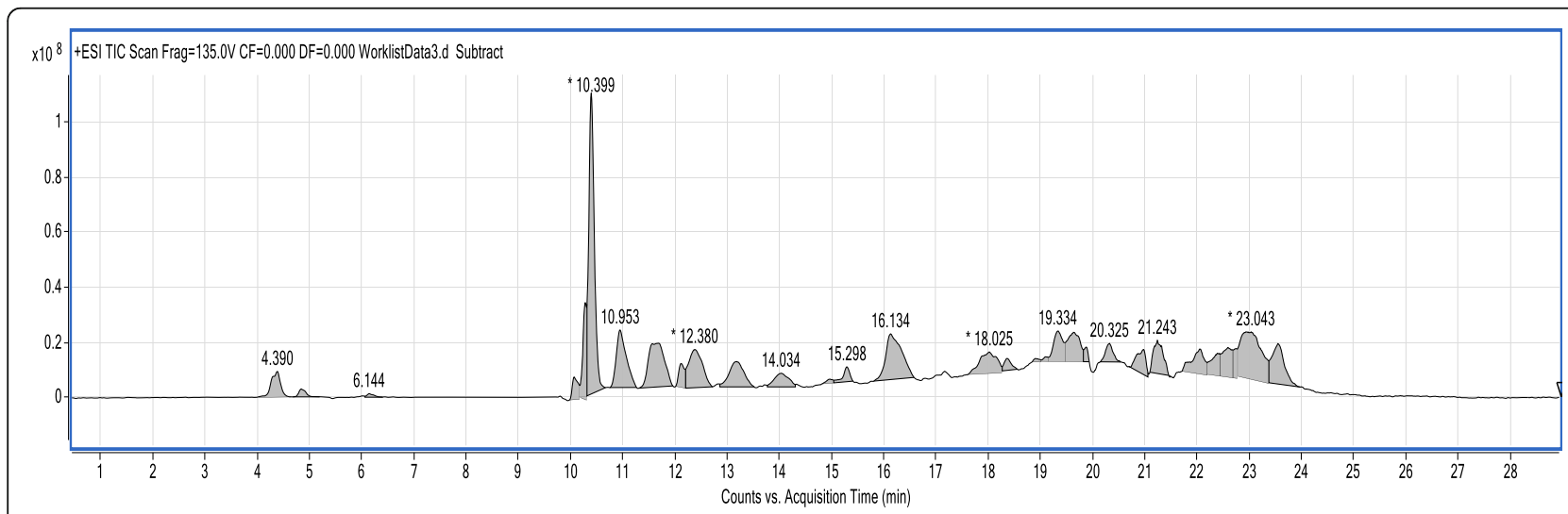

Fig. 3 Chromatogram shows the peaks separated by LC from the band (Rf3) 


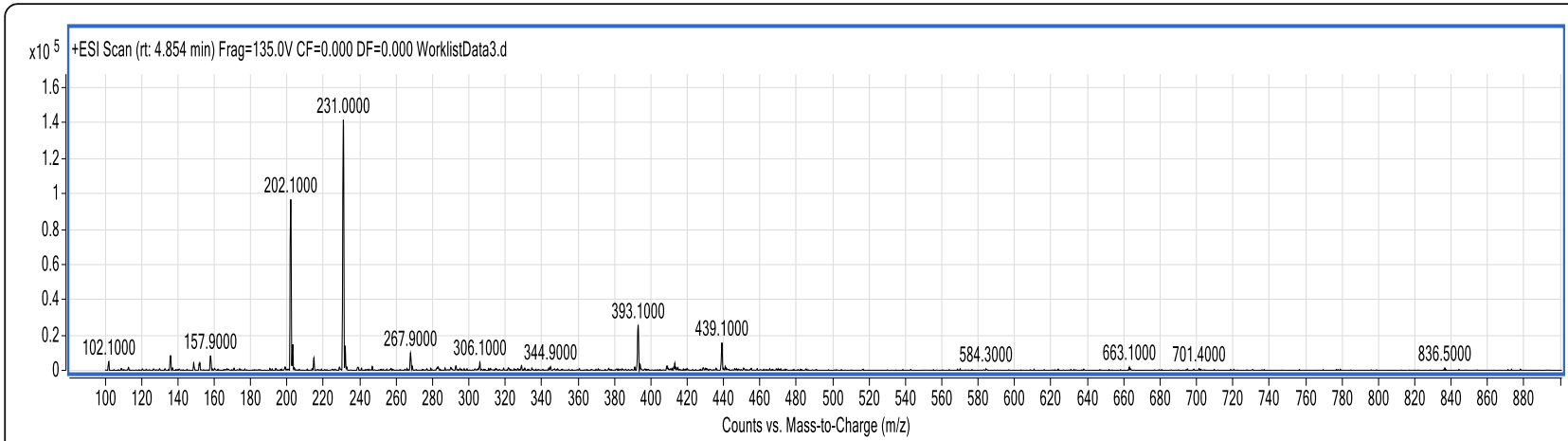

Fig. 4 Mass chart shows the fragment ions of 7-oxocurvularin

(TLC) plate was then placed in a glass jar previously saturated with a developing solvent system of toluene to ethyl acetate to formic acid (6:3:1) (v/v). The glass jar was covered tightly. The developing system was left to rise on the TLC plate, until it reached the solvent front. The developed chromatogram was examined visually and observed under short $(254 \mathrm{~nm})$ and long $(366 \mathrm{~nm})$ wavelength ultraviolet light (UV). The retention factor (Rf) values of the separated spots were determined subsequently. For the detection of bioactive compounds, each band was scraped off the plate, eluted with methanol, and filtered, using a filter paper. The concentration of $\mathrm{LC}_{50}$ was prepared from each band and subjected to assay against $T$. urticae.

\section{Separation and identification of the most active compound/s} Liquid column chromatography-mass spectrometry (LCMS/MS) was used to separate active compounds in the highest active band. The band $\left(\mathrm{Rf}_{3}\right)$ was subjected to identification on Agilent LC-MS/MS (Agilent Technologies, USA) that consists of C18 column model G1316A equipped with a diode array detector (model G1315D) and coupled to a 6420 Triple Quadrupole mass spectrometer equipped with an electrospray ionization (ESI) source operating in positive ionization mode. The mobile phase consisted of $5 \mathrm{mM}$ ammonium formate containing $0.1 \%$ formic acid (solvent A) and acetonitrile (solvent B). A total of $5 \mu \mathrm{l}$ of the sample was injected. The gradient elution program for LC analysis was applied as follows: 0-2 min, $40 \%$ B; $2-12$ min, $40-85 \%$ B; $12-15$ min, $85-90 \%$ B; $15-$ $35 \mathrm{~min}, 90-95 \% \mathrm{~B}$ at a flow rate of $0.3 \mathrm{ml} \mathrm{min}^{-1}$ and the column temperature was set to $35^{\circ} \mathrm{C}$. The MS analysis used full-scan mode with the mass range set to 100-1200 $\mathrm{m} / \mathrm{z}$ in positive and mode. The conditions of the ESI source were as follows: drying gas, high-purity nitrogen $\left(\mathrm{N}_{2}\right)$, drying gas temperature was set to $350^{\circ} \mathrm{C}$, drying gas flow-rate was $11 \mathrm{~L} / \mathrm{min}$, the nebulizing gas $\left(\mathrm{N}_{2}\right)$ was set at a pressure of $45 \mathrm{psi}$, a potential of $3500 \mathrm{~V}$ for the positive ionization mode was applied to the tip of the capillary, and the fragmentation voltage was $130 \mathrm{~V}$. The acquisition and data analysis were controlled using Agilent LC-MS Software (Agilent, USA). The identification of the separated compounds was carried out by comparing their retention times and mass spectra provided by ESI-MS with the data obtained from previous studies that are carried out on the same $A$. melleus as well as those of authentic standards when available.

\section{Data analysis}

Control is corrected according to Abbott's formula (Abbott 1925).

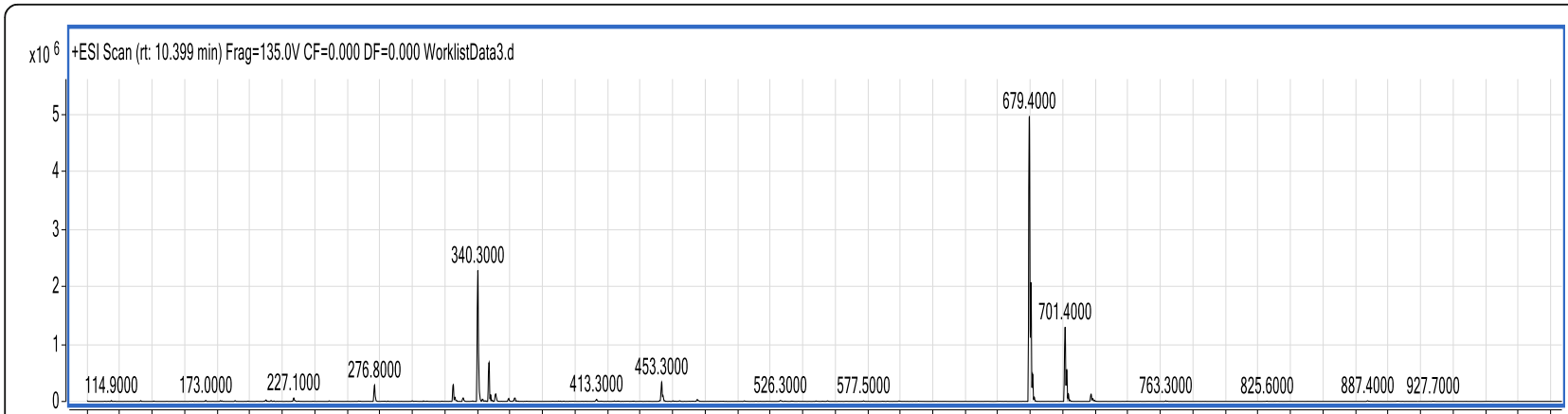

100120140160180200220240260280300320340360380400420440460480500520540560580600620640660680700720740760780800820840860880900920940960980 Counts vs. Mass-10-Charge $(\mathrm{m} / \mathrm{z})$

Fig. 5 Mass chart shows the fragment ions of nodulisporic acid 


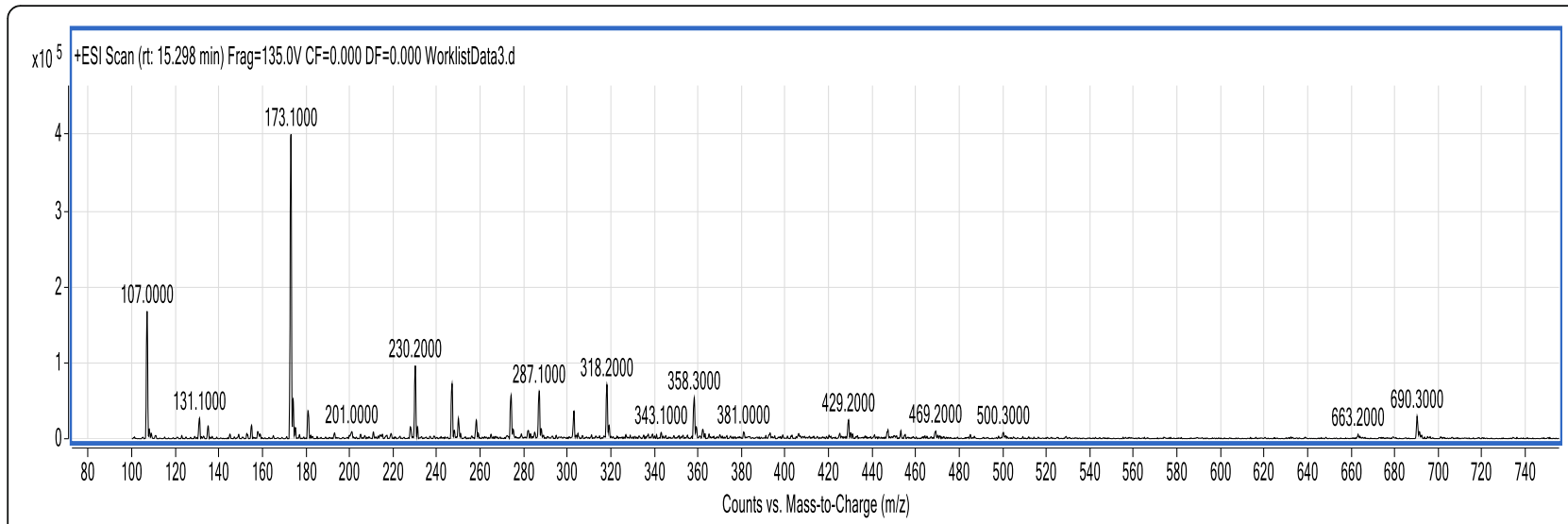

Fig. 6 Mass chart shows the fragment ions of mellamide

$$
\text { Corrected mortality }=\frac{T-C}{100-C} \times 100
$$

where $T=$ dead mites in treatment and $C=$ dead mites in control.

Data obtained from each dose-response bioassay were subjected to probit analysis (Finney 1971) to estimate $\mathrm{LC}_{50}$ values. For mortality and ovicidal activity experiments, the number of dead mite individuals and unhatched eggs were counted and analyzed by one-way analysis of variance (ANOVA) $(P=0.05)$. Means were compared by Duncan's test (Duncan 1955). Also, mortality percentages were calculated and corrected according to Abbott's formula (Abbott 1925).

\section{Results and discussion}

\section{Isolation and primary assay of fungi}

Sixty-two fungal strains were isolated from the rhizosphere of different plants and tested for their control activity against the females of $T$. urticae. Thirty-four isolates showed insignificant differences in their efficiency, while 28 showed a considerable control activity against spider mite (Table 1). Among the effective isolates, KF23, KF40, KF45, and KF9, that showed the highest mortality rates, were selected for further experiments. Culture filtrates of KF23, KF9, KF40, and KF45 resulted in $53.69,73.83,50.34$, and $67.11 \%$ mortality rate, respectively, 5 days after exposure. Similarly, the culture filtrates of $B$. bassiana and $M$. anisoplae highly reduced mite population (Yun et al. 2017). The obtained results were relatively higher than mortality rates of HtCRMB isolate of Hirsutella thompsonii Fisher that only exhibited $55.90 \%$ on $T$. urticae and citrus rust mite, Phyllocoptruta oleivora Ashmead, 9 days after application (Aghajanzadeh et al. 2006). Mehdi (2006) studied the effect of culture filtrates of some fungal isolates and found that the highest contact toxicities were 52.4, 52.4, 48.4, and $50.4 \%$, exhibited by Alternaria alternata, A. terreus, Trichoderma viridae, and Eurotium eurotiorum, followed by A. pluriseptata, Stachybotrys atra, Trichoderma harzianum, T. koningii, and Ulocladium chartarum showed mortality rates of 42.5, 42.5, 46.5, 43.5, and $39.6 \%$, respectively.

Morphological identification of the most effective isolates Isolate KF23 grown on Czapek's agar media forming colony covered with dense layer of sclerotia and

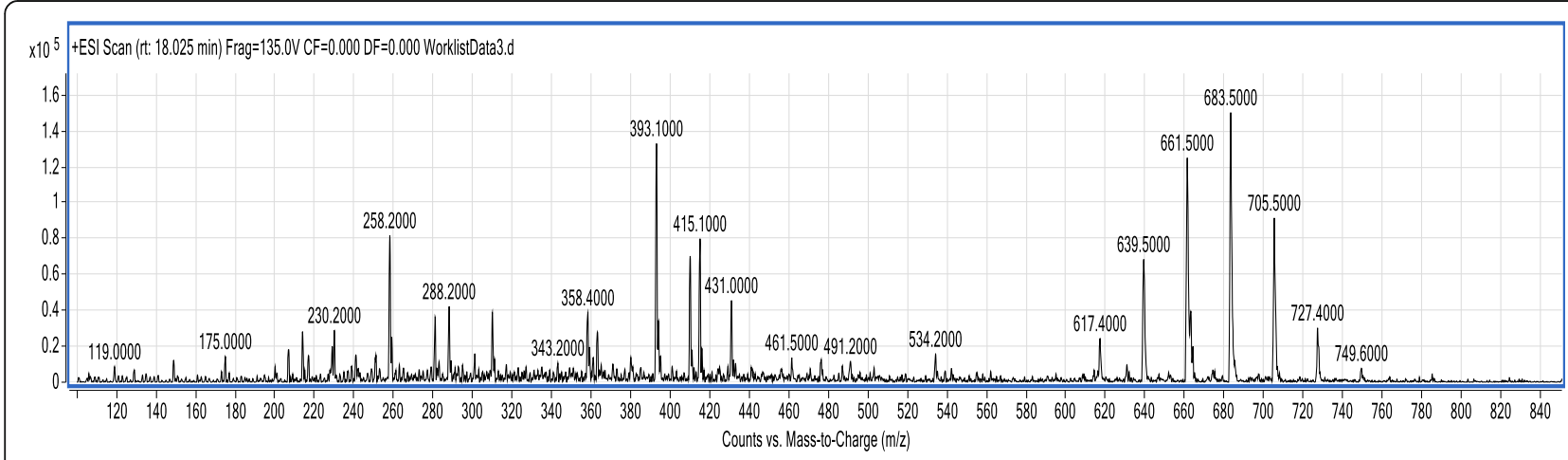

Fig. 7 Mass chart shows the fragment ions of ochratoxin $C$ 


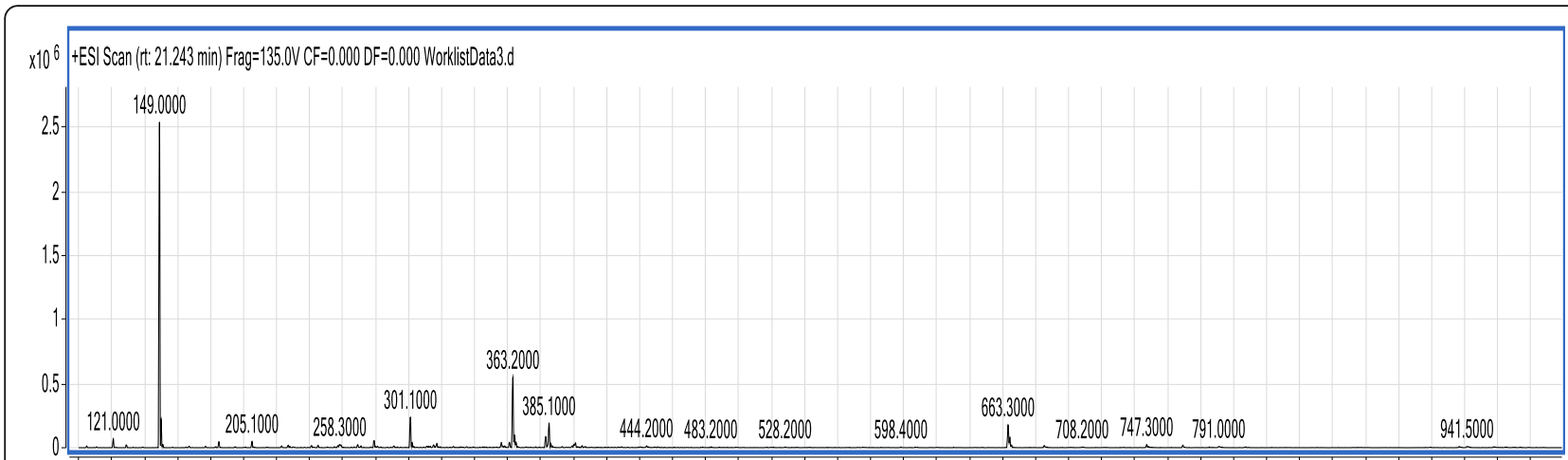

120140160180200220240260280300320340360380400420440460480500520540560580600620640660680700720740760780800820840860880900920940960980 Counts vs. Mass-to-Charge (m/z)

Fig. 8 Mass chart shows the fragment ions of 6-(4'-hydroxy-2'-methyl phenoxy)-(-)- (3R)-mellein

conidiophores absent or produced sparingly in the center. Conidial structures are more abundant in older cultures. Sclerotia were yellow to brown and hard and slightly rounded. This isolate was confirmed as Aspergillus melleus Yukawa at the Mycological Centre, Faculty of Science, Assiut University, Egypt. Isolate KF40 was grown on Czapek's medium forming a colony, colored dark orange yellow with yellow reverse. The colony attained a diameter of $31 \mathrm{~mm}$ after 7 days at $25^{\circ} \mathrm{C}$. Isolate KF40 was identified as A. terreus, according to Raper and Fennell (1965). Isolate KF9 was grown on potato dextrose agar medium producing flattened, black gray colony with white, lobed edges and dark yellow reverse. Growth was relatively slow and characterized by an abundance of olive green ascocarps with ascomal hairs. Spores were pale brown and lemon-shaped. These characters are matching well with Chaetomium globosum (Domsch et al. 1980). The isolate KF45 grew rapidly on Czapek's agar forming green colony with purple shade. Cleistothecia are scattered on the colony, greencolored, and globose. Microscopic examination showed that ascospores were orange with two equatorial crests and in addition to the presence of globose Hülle cells. Accordingly, isolate KF45 was Emericella nidulans (Raper and Fennell 1965).

\section{Effect of crude extract of the selected fungi on adults of T. urticae}

Mortality rates exhibited by the ethyl acetate extract of each of the selected isolates are shown in Table 2. $\mathrm{LC}_{50}$ values on females exhibited by $A$. melleus, $C$. globosum, A. terreus, and $E$. nidulans were 10.27, 22.40, 33.05, and $14.68 \mathrm{mg} / \mathrm{ml}$, respectively. It seems that there are no reports on the acaricidal activity of A. melleus or E. nidulans. The present results proved that the obtained isolates possessed a concentration-dependent strong acaricidal efficacy, since they caused high mortality rates in mite population at the concentration of $30 \mathrm{mg} /$ $\mathrm{ml}$ where $91.67 \%$ and $81.67 \%$ were killed by A. melleus and E. nidulans. Also, C. globosum and A. terreus showed mortality rates of $76.67 \%$ and $56.67 \%$ at the highest concentration $(30 \mathrm{mg} / \mathrm{ml})$, respectively. Similarly, the crude extract of Hypocrella raciborskii Zimm at a concentration of $3 \%(\mathrm{w} / \mathrm{v})$ showed residual toxicity of $80 \%$ in 3 days after application (Buttachon and Kijjoa 2013). Santamarina et al. (1987) found that the crude extract $(10 \mathrm{mg} / \mathrm{ml})$ of $P$. funiculosum caused $100 \%$ mortality in the population of Panonychus ulmi on the second day after treatment. Similar results were obtained by Jimenez et al. (1993) who tested P. funiculosum on adult females of $T$. urticae and recorded a mortality rate of $100 \%$ after 3 days.

Effect of crude extracts of the selected fungi on eggs of $T$. urticae

$\mathrm{LC}_{50}$ values exhibited on eggs were $8.81,11.05,23.17$, and $11.66 \mathrm{mg} / \mathrm{ml}$, when eggs of the spider mite were subjected to crude extracts of $A$. melleus, C. globosum, $A$. terreus, and $E$. nidulans, respectively (Table 3 ). Interestingly, the evaluated isolates showed a higher toxicity towards eggs than adults of $T$. urticae. Crude extracts (30 $\mathrm{mg} / \mathrm{ml}$ ) of A. melleus, E. nidulans, and C. globosum inhibited completely the hatchability of eggs. Similarly, fungal filtrates studied by Mehdi (2006) had more toxic action on eggs of $T$. urticae than adults. He also found that the filtrates of Alternaria alternate, A. pluriseptata, Aspergillus terreus, Trichoderma harzianum, T. koningii, T. viride, Eurotium eurotiorum, Ulocladium chartarum, and Stachybotrys atra inhibited hatchability by an average of $65.5,58.3,65.5,60.6,60.6,54.1,40,52$, 49.1, and $49.1 \%$, respectively. Santamarina et al. (1987) reported that the crude extract $(10 \mathrm{mg} / \mathrm{ml})$ of $P$. funiculosum caused $52.17 \%$ reduction in eggs hatching of Panonychus ulmi. 


\section{Identification of $A$. melleus}

A. melleus showed the minimum $\mathrm{LC}_{50}$ value, so it was selected for further investigation. The identification of $A$. melleus was confirmed by DNA sequencing. The alignment of the ITS sequences of fungal isolate KF23 was done by the National Center for Biotechnology Information (NCBI) database. The phyllogenetic analysis showed that KF23 most resemble $A$. melleus strain CBS 112786 (Accession No. FJ491567) with 99\% homology (Fig. 1).

\section{Identification of active metabolites of $A$. melleus}

Partial separation of active compounds in A. melleus crude extract by TLC resulted in five major bands. Four of them were visualized at long UV wavelength at 366 $\mathrm{nm}$ and one was seen under short UV wavelength at $254 \mathrm{~nm}$. A band colored florescent blue at a $\mathrm{Rf}_{1}$ value of 0.97 , florescent green band at $\mathrm{Rf}_{2}$ value of 0.72 , yellow band at $\mathrm{Rf}_{3}$ value 0.55 , blue band at $\mathrm{Rf}_{5}$ of 0.1 , and brown band at $\mathrm{Rf}_{4}$ 0.43. Each of the five bands was eluted by methanol and subjected to toxicity bioassay against females of $T$. urticae. The mortality rates are as shown in Fig. 2. The $\mathrm{Rf}_{3}$ band exhibited the highest mortality percent of $57.05 \%$, followed by $\mathrm{Rf}_{1}(28.52 \%), \mathrm{Rf}_{2}$ (10.07\%), $\mathrm{Rf}_{5}(11.74 \%)$, and $\mathrm{Rf}_{4}(8.39 \%)$. Therefore, it was selected for further purification and identification by LC-MS/MS.

\section{Liquid chromatography/mass spectrometry}

The metabolites in the active fraction separated by TLC, which had $\mathrm{Rf}_{3}$ of 0.55 , were analyzed by LC-MS/MS and identified by comparing to the same authentic compounds. From LC/MS data, 13 compounds were detected (Fig. 3). Only five compounds were identified, while the others are needed further studies for identification.

The first identified one appeared on liquid chromatography profile at a retention time (Rt) of $4.854 \mathrm{~min}$ had a molecular mass of 306 resulting from ESI-MS $\mathrm{m} / z=306$ $\left[\mathrm{M}^{+}\right]$; it might be 7-oxocurvularin (Fig. 4) and it had the molecular formula $\mathrm{C}_{16} \mathrm{H}_{18} \mathrm{O}_{6}$. The second identified compound appeared at Rt $10.399 \mathrm{~min}$ and a molecular mass of 679 deduced from $\mathrm{m} / \mathrm{z}$ of $679\left[\mathrm{M}^{+}\right]$might be a nodulisporic acid with fragment ion at $m / z=702[\mathrm{M}+$ $\mathrm{Na}$ ] deduced from $m / z 701$ [M - 1] (Fig. 5). The molecular formula of the nodulisporic acid is $\mathrm{C}_{43} \mathrm{H}_{53} \mathrm{NO}_{6}$. The third peak detected at Rt $15.298 \mathrm{~min}$ and a molecular weight of 381 deduced from $\mathrm{m} / z 382[\mathrm{M}+1]$ might be mellamide (Fig. 6) which had the molecular formula of $\mathrm{C}_{23} \mathrm{H}_{31} \mathrm{~N}_{3} \mathrm{O}_{2}$. The fourth identified peak, Rt (18.025 min) with molecular weight of 431, resulted from $\mathrm{m} / z=431$ and fragment ion of $m / z=358$ (Fig. 7). This peak might be ochratoxin $\mathrm{C}$ with a molecular formula of $\mathrm{C}_{22} \mathrm{H}_{22} \mathrm{NO}_{6} \mathrm{Cl}$. The last identified one appeared at $\mathrm{Rt}$
21.243 min with a molecular mass of 301 deduced from $m / z=300[\mathrm{M}-1]$ and fragment ion at $m / z=258[\mathrm{M}+$ 2], 149 [M - 1], and 121[M - 3] (Fig. 8). This peak might be 6-(4'-hydroxy-2'-methyl phenoxy)-(-)-(3R)-mellein $\left(\mathrm{C}_{19} \mathrm{H}_{24} \mathrm{O}_{3}\right)$. Further investigations are required to characterize the other eight compounds. It was reported that A. melleus produces a wide range of polyketides (Garson et al. 1984) and naphthoquinone pigments such as xanthomegnin, viomellein, and viopurpurin (Durley et al. 1975). Similarly, Ondeyka et al. (2003) reported an insecticidal activity of mellamide, xanthomegnin, viomellein, and ochratoxin $\mathrm{A}$ isolated from $A$. melleus against Aedes aegypti. Also, A. melleus produces aspyrone that exhibited nematicidal activity against Pratylenchus penetrans by $80 \%$ at a concentration of $300 \mathrm{mg} / \mathrm{l}$ (Kimura et al. 1996).

\section{Conclusion}

A. melleus, E. nidulans, C. globosum, and A. terreus showed promising acaricidal activities against the twospotted spider mite, T. urticae, females and eggs. Further investigations are still needed to identify their bioactive secondary metabolites and to evaluate their efficacy under greenhouse and field trials.

\section{Abbreviations \\ ANOVA: Analysis of variance; DNA: Deoxyribonucleic acid; ESI: Electrospray ionization; ITS: Internal transcribed spacer; $L_{50}$ : The median lethal concentration; LC-MS/MS: Liquid chromatography-mass spectrometry; NCBI: National Center for Biotechnology Information; PCR: Polymerase chain reaction; PDA: Potato dextrose agar; Rf: Retention factor; rpm: Revolutions per minute; Rt: Retention time; TLC: Thin layer chromatography; UV: Ultraviolet}

\section{Acknowledgements}

Thanks are due to Prof. Mohamed Abdelaziz Balah, Plant Protection Department, Desert Research Center, for the interpretation of LC-MS/MS data and identification of the separated compounds.

\section{Authors' contributions}

The conception and design of the study were done by all authors; the last author $(\mathrm{GAH})$ performed the experimental part under the supervision of MEO, AAAE, and MAN. The analysis and interpretation of the data were done by the first author (MEO) and AAAE. Both MAN and GAH prepared the manuscript draft; then the manuscript was revised for important intellectual content by MEO and AAAE. All authors read and approved the final manuscript.

\section{Funding}

There are no funding sources for this manuscript.

\section{Availability of data and materials}

The data and material of this manuscript are available on reasonable request.

Ethics approval and consent to participate

This article does not contain any studies with human participants or animals.

\section{Consent for publication}

The manuscript has not been published in completely or in part elsewhere.

Competing interests

The authors declare that they have no competing interests. 


\section{Author details}

'Department of Botany and Microbiology, Faculty of Science, Helwan University, Cairo, Egypt. ${ }^{2}$ Department of Plant Protection, Desert Research Centre, Cairo, Egypt.

Received: 8 May 2019 Accepted: 29 August 2019

Published online: 14 September 2019

\section{References}

Abbott WS (1925) A method of computing the effectiveness of an insecticide. Econ Entomol 18(2):265-267

Aghajanzadeh S, Mallik B, Chandrashekar SC (2006) Toxicity of culture filtrate of Hirsutella thompsonii Fisher against citrus rust mite, Phyllocoptruta oleivora Ashmead (Acari: Eriophyidae) and two spotted spider mite, Tetranychus urticae Koch (Acari: Tetranychidae). Int J Agric Biol 8(2):276-279

Attia S, Grissa KL, Lognay G, Bitume E, Hance T, Mailleux AC (2013) A review of the major biological approaches to control the worldwide pest Tetranychus urticae (Acari: Tetranychidae) with special reference to natural pesticides. J Pest Sci 86(3):361-386

Buttachon S, Kijjoa A (2013) Acaricidal activity of Hypocrella raciborskii Zimm. (Hypocreales: Clavicipitaceae) crude extract and some pure compounds on Tetranychus urticae Koch (Acari: Tetranychidae). Afr J Microbiol Res 7(7):577-585

Culliney TW (2014) Crop losses to arthropods. In: Pimentel D, Peshin R (eds) Pesticide problems. Integrated pest management, vol 3. Springer, Dordrecht, pp 201-225

Domsch KH, Gams W, Anderson TH (1980) Compendium of soil fungi. Academic, London

Duncan DB (1955) Multiple range and multiple F-tests. Biometrics 11(1):1-42

Durley RC, MacMillan J, Simpson TJ, Glen AT, Turner WB (1975) Fungal products. Part XIII. Xanthomegnin, viomellin, rubrosulphin, and viopurpurin, pigments from Aspergillus sulphureus and Aspergillus melleus. J Chem Soc Perkin Trans 1(2):163-169

Fasulo TR, Denmark HA (2000) Two spotted spider mite, Tetranychus urticae Koch (Arachnida: Acari: Tetranychidae). University of Florida Cooperative Extension Service, Institute of Food and Agricultural Sciences, EDIS http://entnemdept. ufl.edu/creatures/orn/twospotted_mite.htm

Finney DJ (1971) Probit Analysis, 3rd edn. Cambridge University Press, London

Garson MJ, Staunton J, Jones PG (1984) New polyketide metabolites from Aspergillus melleus: structural and stereochemical studies. J Chem Soc Perkin Trans 1:1021-1026

Horikoshi R, Goto K, Mitomi M, Oyama K, Sunazuka T, Ōmura S (2017) Identification of pyripyropene $\mathrm{A}$ as a promising insecticidal compound in a microbial metabolite screening. J Antibiot 70(3):272

Jimenez M, Atienza J, Hernandez E (1993) Bioproduction of an extract from Penicillium funiculosum Thom with activity against Ceratitis capitata and Tetranychus urticae. Appl Microbiol Biotechnol 39(4-5):615-616

Kimura Y, Nakahara S, Fujioka S (1996) Aspyrone, a nematicidal compound isolated from the fungus, Aspergillus melleus. Biosci Biotechnol Biochem 60(8):1375-1376

Marcic D (2012) Acaricides in modern management of plant-feeding mites. J Pest Sci 85(4):395-408

Mehdi HMR (2006) The effect of some fungi in biocontrol in two spotted spider mite Tetranychus urticae (Koch.) (Tetranychidae: Acari). J Basrah Res (Sciences) 32(2B):12-26

Neal JW Jr, Lindquist RK, Gott KM, Casey ML (1987) Activity of the thermostable p-exotoxin of Bacillus thuringiensis Berliner on Tetranychus urticae and T. cinnabarinus. J Agric Entomol 4(1):33-40

Ondeyka JG, Dombrowski AW, Polishook JP, Felcetto T, Shoop WL, Guan Z, Singh SB (2003) Isolation and insecticidal activity of mellamide from Aspergillus melleus. J Ind Microbiol Biotechnol 30(4):220-224

Putter I, Mac Connell JG, Preiser FA, Haidri AA, Ristich SS, Dybas RA (1981) Avermectins: novel insecticides, acaricides and nematicides from a soil microorganism. Experientia 37(9):963-964

Ragavendran C, Natarajan D (2015) Insecticidal potency of Aspergillus terreus against larvae and pupae of three mosquito species Anopheles stephensi, Culex quinquefasciatus, and Aedes aegypti. Environ Sci Pollut Res 22(21): 17224-17237

Raper KB, Fennell DI (1965) The genus Aspergillus. The Williams \&Wilkins company, Baltimore (686 pages)

Roobakkumar A, Babu A, Kumar DV, Sarkar S (2011) Pseudomonas fluorescens as an efficient entomopathogen against Oligonychus coffeae Nietner (Acari: Tetranychidae) infesting tea. J Entomol Nematol 3(5):73-77
Santamarina MP, Jimenez M, Sanchis V, Garcia F, Hernandez E (1987) A strain of Penicillium funiculosum Thorn with activity against Panonychus ulmi Koch (Acar.: Tetranychidae). J Appl Entomol 103(1-5):471-476

Srivastava CN, Maurya P, Sharma P, Mohan L (2009) Prospective role of insecticides of fungal origin. Entomol Res 39(6):341-355

Vargas Mesina RR (1993) Thuringiensin toxicity to Tetranychus urticae Koch and Panonychus ulmi (Koch) (Tetranychidae) and effects on cuticle development of immature stages of T. urticae. Ph.D. Dissertation, Lincoln University, New Zealand

White TJ, Bruns T, Lee S, Taylor J (1990) Amplification and direct sequencing of fungal ribosomal RNA gene for phylogenetics. In: Innis MA, Gelfand DH, Sninsky JJ, White TJ (eds) PCR protocols: a guide to methods and applications. Academic, San Diego, pp 315-322

Wu Y, Liu X (1997) Toxicity and biological effect of abamectin on Tetranychus cinnabarinus in lab. Acta Agric Boreali Sin 12(1):108-111

Yun HG, Kim DJ, Lee JH, Ma Jl, Gwak WS, Woo SD (2017) Comparative evaluation of conidia, blastospores and culture filtrates from entomopathogenic fungi against Tetranychus urticae. Int J Ind Entomol 35(1):58-62

\section{Publisher's Note}

Springer Nature remains neutral with regard to jurisdictional claims in published maps and institutional affiliations.

\section{Submit your manuscript to a SpringerOpen ${ }^{\circ}$ journal and benefit from:}

- Convenient online submission

- Rigorous peer review

- Open access: articles freely available online

- High visibility within the field

- Retaining the copyright to your article

Submit your next manuscript at $\boldsymbol{\nabla}$ springeropen.com 